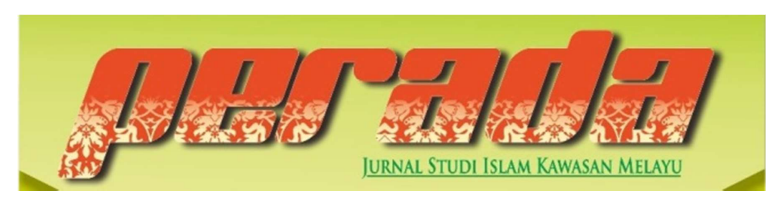

Perada: Jurnal Studi Islam Kawasan Melayu

ISSN 2656-7202 (P) ISSN 2655-6626 (O)

Volume 3 Nomor 1, Januari-Juni 2020

DOI: https://doi.org/10.35961/perada.v3i1.77

\title{
RELIGIUSITAS MASYARAKAT TANJUNG SEBAUK MENURUT ISLAM (PERSPEKTIF SOSIOLOGI AGAMA)
}

\author{
Joko Wibowo \\ STAIN Sultan Abdurrahman Kepulauan Riau \\ jokowibowo@stainkepri.ac.id
}

\begin{abstract}
ABSTRAK
Artikel ini bertujuan melihat tentang religiusitas masyarakat Tanjung Sebauk, Kota Tanjungpinang, Provinsi Kepulauan Riau. Kebergamaan seseorang biasanya ditunjukan dengan pemahaman terhadap ajaran, doktrin dan norma agama dan juga terejawantahkan dalam ahklak, sikap dan prilaku sehari-hari. Religuisitas juga tercermin dalam kehidupan sosial dan bahkan kehidupan pribadi seseorang. Dalam penelitian ini disimpulkan bahwa adat istiadat yang dilakukan masyarakat Tanjung Sebauk selalu berupaya melandaskan pada norma-norma Islam sebagaimana kebanyakan masyarakat melayu umumnya, khususnya tradisi dan ritual yang telah berlangsung lama dalam kehidupan sosial budaya masyarakat. Namun secara indivisual dan tingkat pemantapan terhadap ajaran agama masih perlu mendapat perhatian dari berbagai pihak, khususnya dari kalangan ulama atau tokoh agama di Tanjungpinang. Bahkan perlu juga pemberian pemahaman dalam upaya memanfaatkan lingkungan sebagai sumber penghasilan berdasarkan ajaran agama.
\end{abstract}

Abstract: This article aims to look at the religiosity of the people of Tanjung Sebauk, Tanjungpinang City, Riau Islands Province. The similarity of a person is usually shown by an understanding of the teachings, doctrines and religious norms and is also embodied in morals, attitudes and daily behavior. Religion is also reflected in one's social life and even in one's personal life. In this study, it is concluded that the customs carried out by the people of Tanjung Sebauk always try to be based on Islamic norms like most Malay people in general, especially traditions and rituals that have been going on for a long time in the social and cultural life of the community. However, individually and the level of consolidation of religious teachings still needs the attention of various parties, especially from among ulama or religious leaders in Tanjung Pinang. In fact, it is also necessary to provide understanding in an effort to utilize the environment as a source of income based on religious teachings.

Kata Kunci : religiusitas, masyarakat pesisir, tanjung sebauk 


\section{PENDAHULUAN}

Islam memiliki ajaran yang berdimensi lahiriyah dan dzahiriyah untuk mengisi relung jiwa manusia. Ajaran yang dibawah Islam mengajar manusia untuk menjadi hamba yang mengabdi kepada Allah dan menjadi khalifah di bumi. Sebab itu, apa yang diyakini, dipikirkan, disikapi dan dilakukan, haruslan sesuai dengan norma dan doktrin ajaran Islam. Dalam kehidupan nyata di masyarakat, banyak orang Islam yang mereka tidak melakukan perbuatan yang sesuai dengan konsep Islam. Ada yang mengerjakan amal perbuatan sesuai dengan konsep Islam namun lemah keyakinannya. Muslim yang tidak sepenuhnya menjalankan ajaran Islam, maka ia belum menjadi bagian dari muslim yang seutuhnya (kaffah).

Setiap pribadi manusia juga memiliki kencendrungan masing-masing. Bagi yang mempunyai suatu keinginan atau target, dia bisa mendapatkannya. Setiap sesuatu baik waktu, tempat dan seseorang dalam kehidupan memiliki potensi yang berbeda beda. Untuk memperoleh menfaat dari potensi yang ada tidak semua faham, bagaimana dapat memperoleh manfaat dari potensi yang ada. Keadaan yang sangat parah lagi, tidak tahu kalau ada potensi yang akan memberikan keberuntungan. Jadi masalah di sini yang harus dicarikan solusi menyadarkan akan adanya peluang yang dapat mewujudkan yang menjadi impian.

Kemahuan untuk mencapai suatu maksud terkhusus cita cita dibutuhkan yang namanya kebulatan tekad, tabah dan tekun. Dalam pergaulan yang sering kita dengar dengan sebutan "Azam". Maka kebulatan tekad, tabah dan tekun, sangat dibutuhkan terlebih lagi bila mengguna- kan istilah kata mewujudkan impian. Suatu impian seseorang merupakan sesuatu yang dimiliki tetapi belum nyata, belum ada. Supaya terlepas dari sebutan orang sebagai penghayal.
Hubungan antara agama dan orang sebagai dua hal yang saling mempengaruhi. Agama mem pengaruhi jalannya aktifitas orang, demikian juga pertumbuhan orang, sangatlah dipengaruhi pemikiran terhadap agama. ${ }^{1}$ Peranan pendidikan agama sangatlah penting dalam kehidupan, karena pada hakikatnya pendidikan agama adalah suatu landasan utama, untuk terbentuknya orang yang sukses, kratif dan bermoral, yang berakhlakul karimah. Orang yang berpendidikan agama akan berbeda dengan orang yang tak berpendidikan sama sekali. Dia akan selalu berpikir pada setiap apa yang akan dilakukannya dan selalu merendahkan diri dari apa yang dimiliki, seperti dalam pribahasa Indonesia "padi semakin berisi semakin merunduk." Dan tidak menyerah dengan keadaan yang sulit dan serba keterbatasan. Beda halnya dengan orang yang tak terdidik sama sekali mereka hanya pasrah dengan keadaan. Kalaupun berbuat akan selalu bertindak tanpa memikirkan apa yang akan terjadi selanjutnya. Dalam fikirannya hanyalah bagaimana memperoleh keuntungan sebanyak banyaknya dan segala cita-citanya tercapai. Dan tidak perduli orang lain dan lingkungan rugi dan menderita.

Orang religi bersifat dan bersikap berdasarkan apa yang ada dalam ajarkan agama, melalui pendidikan agama yang merupakan proses pendidikan dan memberikan pengetahuan, membentuk kepribadian, sikap serta keterampilan orang dalam mengamalkan norma, nilai, serta ajaran agamanya. Dalam hal inilah, Mukti Ali menilai perkembangan agama sangat dinamis dan tergantung dari pe- mahaman serta peraktek sosial keagamaan orang sehingga layak menjadi lahan penelitian sebab apa yang diperaktekkan orang

1 Ali Amran, 'Peranan Agama Dalam Perubahan Sosial Masyarakat', HIKMAH: Jurnal Ilmu Dakwah Dan Komunikasi Islam, 2.1 (2015), 23-39. 
merupakan bagian dari agama sebagai sebuah kajian ilmiah, karena ajaran agama melahirkan gejala sosial. Dalam pendapat lain, seperti halnya Amin Abdullah, kajian tersebut sebagai kajian agama secara historis sebab agama sebagai fenomena manusiawi. Agama juga mengambil bentuk dalam berbagai dimensi waktu dan tempat. ${ }^{2}$

Dalam kaca mata tersebut, maka artikel ini hendak mengupas tentang religiusitas masyarakat di Kampung Tanjung Sebauk. Daerah ini merupakan satu dari beberapa kampung yang ada di Kecamatan Kota Tanjung Pinang Kepulauan Riau. Terletak di tepi laut dan dekat dengan kantor wali kota Tanjungpinang. Letak Tanjung Sebauk berdampingan dengan senggarang yang daerahnya sering berdatangan pengunjung yang bukan saja dari orang orang lokal, tidak kurang juga pendatangnya dari orang orang luar, bahkan dari Negara tetangga.

Apabila dilihat dari hasil identifikasi terhadap kondisi obyektif penghidupan di Masyarakat Tanjung Sebauk belum nampak kesan adanya potensi yang melebihi dari yang lain. Dan kenyataan yang ada, kita jumpai keadaannya sama dengan kampung kampung yang lain. Berarti Masyarakat Tanjung Sebauk belum mengambil manfaat dari berbagai nikmat yang telah Allah berikan. Sedangkan agama mengajarkan jangan menyia nyiakan sesuatu dari nikmat Allah. Dengan kondisi ini, tersingkap begitu lemah pengamalan ajaran agama.

Supaya potensi yang ada dapat diambil manfaatnya oleh Masyarakat Tanjung Sebauk, harus ada upaya meningkatkan perhatian dan motivasi berupa pendidikan dan pemahaman agama, training dalam kehidupan yang harus didampingi. Oleh karenanya, perlu dilakukan analisis ini dilihat

2 M. Amin Abdullah, Studi agama: normativitas atau historisitas? (Pustaka Pelajar, 1996). begitu penting bagi masyarakat Tanjung Sebauk khususnya dan sebagai khazanah bagi dunia keilmuan

Berdasarkan hal tersebut, maka fokus kajian ini hendak megulas tentang religiusitas masyarakat Tanjung Sebauk menurut jaran Islam dengan pespektif sosiologi agama. Penelitian ini merupakan dengan metode kualitatif dengan sumber data data dari lapangan dan referensi terkait. Metode penulisan mengunakan analitis deskriptif, yaitu usaha untuk mengumpulkan dan menyusun suatu data dan kemudian dialukan analisis pada data tersebut. ${ }^{3}$

Deduksi yaitu suatu cara menarik kesimpulan dari yang umum ke yang khusus, hal ini meru- muskan cara atau proses berfikir indukasi yatiu berangkat dari fakta fakta atau peristiwa peristiwa khusus dan kongkrit, kemudian digeneralisasikan menjadi kesimpulan yang bersifat umum. ${ }^{4}$

\section{NILAI-NILAI ISLAMI}

Untuk memperoleh kemajuan bagi setiap orang diajarkan oleh Nabi Muhammad SAW. yang ajarannya berasalkan dari Allah. Ajaran Islam bersifat rahmatal lil'alamin. Allah merahamati semua makhluk Nya dan tidak mencari kenikmatan dan keuntungan dari makhluknya. Seperti perintah salat dalam Islam wajib dikerjakan, bukanlah perintah itu untuk kepentingan Allah. Melainkan Allah ingin memberikan rahmat, kenikmatan bagi orang yang mendirikan salat. Seperti setiap orang yang mempunyai masalah ingin memperoleh penyelesaian dari masalah yang sedang dihadapi.

Allah memudahkan bagi anak Adam transportasi di daratan dan di lautan untuk

3 Winarno Surakhmad, Pengantar Penelitian Ilmiah: Dasar, Metode Dan Teknik (Tarsito, 1990).

4 Sutrisno Hadi, 'Metode Research', Yogyakarta: Andi Offset, 1987. 
memperoleh penghidupan. Allah mengangkat derajat dan dihantarkan ke pintu kebahagiaan bumi langit dan seisinya, di ciptakan dan di sediakan untuk kepentingan umat manusia. Artinya dipersilahkan untuk manusia memanfaatkan dan menikmati. Dari ikan binatang yang dapat dimakan, dan sebagian dapat dikendarai, sampai kepada ada tumbuh-tumuhan, buah-buahan, mutiara mutiara di dalam laut, logam di dalam bumi, matahari dan berjuta-juta kekayaan lainnya yang ada di dalam alam jagat raya ini. Sangatlah besar perhatian Islam pada manusia. Fasilitas disiapkan dilengkapi dan semua kebutuhan dicukupi. Dalam pandangan Islam ini semua tanda besarnya perhatian Allah kepada manusia. Dan juga sebagai tanda kebesaran Allah yang Maha Pengasih dan Maha Penyayang.

Di antara ajaran Islan yang pertama setelah seseorang menerima Islam dan Allah menjadi sesembahannya (Tuhan). Maka setiap muallaf yang baru mengikrarkan syahadatain, dia harus mengerjakan mandi wajib. Bersih dan suci dalam ajaran Islam mendapat perhatian besar. Kondisi kotor akan menimbulkan masalah baik bagi seseorang dan masyarakat. Orang yang tidak menjaga kebersihan hidupnya tidak sehat dan bisa menjadi sumber penyakit, tempat berkebangnya penyakit.

Dengan tidak memperhatikan atau peduli pada kebersihan yakni tidak bersungguh sungguh untuk mendapatkan membersihkan keraguan terhadap kebenaran ajaran yang disampaikan oleh nabi Muhammad SAW yang bisa mengakibatkan sakitnya hati. Kehidupan menjadi tidak nyaman lagi, masalah bermunculan, musibah dan bencana menghajar. Begitu besar akibat dari tidak respon dengan kebersihan baik secara lahir dan batin. Bagi orang yang suka kotor jangankan meraih kehidupan akhirat kehidupan dunia saja dia susah dan akan menderita. Tidak ada orang yang mau dekat dengannya, sebab tidak ada orang yang senang dengan kondisi yang kotor apalagi berbauh yang tidak sedap. Dari ajaran kebersihan dalam Islam hendaknya terbuka pemikiran kita dan membentuk keyakinan, betapa besarnya dampak kebersihan dari perbuatan seseorang pada kehidupan dunia dan akhirat. ${ }^{5}$ Dalam hal ini, termasuk juga kebersihan dalam mencari rezeki, kebersihan hati dalam berbuat suatu pekerjaan dan kebersihan dalam bersikap dan sebagainya.

Ajaran lainnya ialah memiliki keyakaninan terhadap potensi dirinya dan berusaha maksimal dalam melakukan suatu perbuatan. Dengan keyakinan yang mantap seseorang dapat berfikir dengan tenang dan berbuat dengan penuh harapan kepada Allah SWT. dalam genggamannya semua kebaikan dan kesuksesan. Setelah berusaha maksimal, maka bermohon akan kebaikan dan berlindung dari keburukan.

Kemajuan dan keberhasilan diraih dengan ilmu dan ketrampilan. Berilmu belum tentu tram- pil. Sedangkan orang yang trampil sudah tentu memiliki ilmu. Orang trampil, kreatif mampu mengetahui potensinya dan dapat menambah kemampuannya. Dengan berbagai program kita akan memperoleh berbagai mengalaman yang akan mendatangkan manfaat dan keuntungan.

Kemudahan dan kesuksesan akan selalu bersama dengan orang orang yang yakin pada ajaran agama. Dari orang-orang yang yakin dan mengamalkan ajaran agama lahirlah masyarakat yang sejahtra dan bahagia. Sebagaimana firman dalam AlQur'an surat al Anfal (8) ayat 96-99, yang artinya, "Iikalau Sekiranya penduduk negeri negeri beriman dan bertakwa, pastilah Kami akan melimpabkan kepada mereka berkah dari langit

5 Majelis Ulama Indonesia, 'Air, Kebersihan Dan Kesehatan Lingkungan Menurut Ajaran Islam’, 2019. 
dan bumi, tetapi mereka mendustakan (ayat-ayat Kami) itu, Maka Kami siksa mereka disebabkan perbua- tannya."

Jadi dapat dipahami bahwa ajaran Islam bukan hanya membahas masalah keyakinan saja. Ajaran agama Islam sangat luas, keimanan seseorang belum dikatakan sempurna apabila tidak mengamalkan seluruh ajaran Islam. Di antara ajaran Islam ada Imaniyah, ubudiyah, muamalah, dan akhlak. Siapapun orangnya, dari manapun asal, suku, dan bangsanya sangat menginginkan akan kehidupan yang layak, bahagia dan sejahtera. Setidak-tidaknya keinginan yang didapatkan kemerdekaan atau kebebasan untuk berbuat dan menentukan kehidupan sekarang dan kehidupan pada masa yang akan datang. ${ }^{6}$

Dalam ajaran agama Islam orang yang berbuat baik akan mendapatkan kebaikan. Orang yang memiliki tekad bulat dalam kebenaran yang akan memperoleh keselamatan dan kesuksesan. Dengan pendirian teguh seseorang akan berjalan tegak dan gagah. Setidaknya ada dua hal yang perlu ditanam pada diri seorang muslim dalam setelah keyakinan kepada Allah dalam menjali kehidupan di dunia secara mandiri, yakni aspek intelektual dan sosial.

Pertama, intelektualistas. Ciri lain orang mandiri memiliki hasrat bersaing untuk maju demi kebaikan dirinya. Dalam menjalankan tugas-tugasnya Ia melakukan tugas yang diyakini benar Meskipun dia dikritik atau diancam orang lain. Bertanggung jawab terhadap apa yang dilakukannya Ia mau mengakui kesalahan secara terbuka dan berusaha belajar dari kesalahan. Dia mau mengambil resiko dan mau berupaya keras meraih prestasi.

6 Musaddad Harahap, 'Refleksi Dinamika Kebebasan Akademis Dalam Pendidikan Islam', Jurnal Pendidikan Agama Islam Al-Thariqah, 1.1 (2016), 87-103.
Orang yang mandiri, adalah orang yang mampu memprogram emosinya. ${ }^{7}$ Dari aktifitas yang tidak jelas, yaitu aktifitas yang tidak mendatangkan manfaat hanya tertawa tawa, senang senang. Tidak tahu perubahan kebaikan apa yang terjadi. Dan keuntungan apa yang diperoleh. Boleh jadi kerugian. Sedangkan orang yang mampu memprogram emosinya akan memperoleh perubahan positif dalam kehidupannya. Mereka memperoleh perubahan dan kemajuan karena tidak ada pada mereka sifat bergantung dengan keadaan yang lemah dan sulit. Sehingga mereka dapat melakukan kreativitas yang membawa ke tingkat kemajuan. Dan secara tidak langsung, lingkungan didekatnya memperoleh kebaikan juga. Keadaan ekonomi, bagi Orang yang mandiri bukanlah masalah besar. Kehidupan yang baik bukan ditentukan oleh ekonomi tetapi ditentukan sejauh mana seseorang mampu mengatur dan menggendalikan keuangannya. Dengan mengutamakan pengeluaran yang membawa perkembangan baik dan mana pengeluaran yang hanya menghabiskan dana. Pengeluaran dana yang membawa perubahan baiknya sedikit dikurangi anggaran atau ditiadakan. ${ }^{8}$ Orang yang paling miskin, hidup bukan hanya berkekurangan tapi sampai tahapan tidak punya harta apa apa, kecuali pakaian yang ditubuhnya. Apabila memiliki kemandirian, dia bisa hidup tanpa memohon belaskasihan. Akal dan tenaganya dengan keman-diriannya dia masih tetap hidup dan kondisi akan dengan kesempatan datang.

7 Lisda Rahmasari, 'Pengaruh Kecerdasan Intelektual, Kecerdasan Emosi Dan Kecerdasan Spiritual Terhadap Kinerja Karyawan', Majalah Ilmiab Informatika, 3.1 (2012).

8 Iswahyudin Iswahyudin, 'Pengaruh Belanja Modal, Belanja Barang Dan Jasa Terhadap Sisa Lebih Pembiayaan Anggaran (Silpa) Kabupaten/Kota Di Sulawesi Tengah', Katalogis, 4.6. 
Menuggu datangnya kesempatan, baik bagi orang orang yang tidak menyakini ajaran ajaran agama, maka sulit bagi mereka untuk menerima apalagi mengikutinya. Sedangkan mereka tidak bisa lari dari kenyataan yang ada, mau tidak mau harus menerima kenyataan yang ada. Jangan sampai ada keyakinan yang buruk berupa tidak ada harapan. ${ }^{9}$ Bagi orang yang beriman, dia yang yakin masih bisa berbuat untuk mendapatkan keinginannya. Dengan cara berdoa dan melakukan ke- baikan atau amal sholeh. Dengan kebaikan yang dilakukan, Allah bisa memberikan perubahan atau solusi. Dengan rajinnya ada orang yang kasihan dan mau memberikn solusi, jujurnya, tutur bahasanya atau kebaikan yang lainnya.

Kemandirian seseorang sangat didukung dengan kemampuan untuk mengatasi berbagai masalah yang dihadapi. Dengan keilmuan dan pengetahuan, kemandirian seseorang akan kokoh. Semua tantangan dan rintangan yang menghadang dapat diselesaikan. Orang seperti ini akan dijadikan figur di masyarakat, tempat bertanya bagi orang yang tidak tahu dan sangat di bu- tuhkan di masyarakat. Kehidupannya akan bahagia didunia dan diakhirat. Sebagaimana sabda Rasulullah : من اراد الدنيا فعليه بالعلم ,ومن ارادالخرة فعليه بالعلم ومن ار ادهما فعليه بالعلم العان

Artinya: Barang siapa menginginkan kehidupan dunia maka wajib dengan berilmu, dan barang siapa menginginkan kehidupan akhirat maka wajib dengan berilmu, Dan barang siapa yang meninginkan kehidupan dunia dan akhirat maka wajib dengan berilmu.

9 Oktaliza Friz, 'Hubungan Antara Harga Diri Terhadap Resiliensi (Ketangguhan Diri) Pada Remaja Di SMA Kartika I-5 Padang' (unpublished PhD Thesis, UPT. Perpustakaan Unand, 2015).
Kedua, aspek sosial. Aspek ini menunjukkan oleh kemampuan mengadakan interaksi dengan orang lain dan dan tidak menunggu aksi dari orang lain. Interaksi baik seseorang akan membuahi berbagai kebaikan. ${ }^{10}$ Orang yang bejiwa sosial ada ditengah masyarakat, berarti adanya kebaikan yang dia la- kukan. Kata pepatah arab man yazro' yahshud artinya siapa yang menanam dia yang akan memanen. Orang sosial berbuat kebaikan akan memperoleh kebaikan. ${ }^{11}$

Dengan penjelasan di atas dapat diperoleh gambaran bahwa sikap mandiri tidak berarti menyendiri atau menganggap dirinya tidak membutuhkan orang lain dalam ke- mandirian terdapat aspek sosial yaitu kemampuan berinteraksi dengan orang lain dalam keman- dirian terdapat aspek sosial yaitu kemampuan berinteraksi dengan orang lain.

Gambaran orang yang tidak Mandiri, berikut ini seperti berikut.

1. Adanya ketakutan atau kekhawatiran salah untuk berbuat, melakukan sesuatu

2. Sikap dan tingkah lakunya didasarkan pada yang dikatakan orang lain bukan atas inisiatif sendiri

3. Adanya perasaan malu untuk bertindak atau mengucapkan perasaan

4. Sering tinggal di dalam suasana yang menyenangkan lebih suka menghindari resiko dan selalu Minta pendapat orang lain

5. Berupaya menutupi kesalahan atau kelemahan

6. Cepat putus asa ketika hasil tidak sesuai rencana atau seperti yang di inginkan

\footnotetext{
10 Rahmasari.

11 Teguh Suripto, 'Manajemen Sdm Dalam Prespektif Ekonomi Islam: Tinjauan Manajemen Sdm Dalam Industri Bisnis', JESI Jurnal Ekonomi Syariab Indonesia), 2.2 (2016), 239-50.
} 
7. Sering mencari jalan pintas yang mudah untuk mencapai tujuan

8. Tidak memiliki inisiatif sesuatu yang dikerjakan berdasarkan perintah dan setiap perintah atau tugas dianggap sebagai beban

Dari gambaran di atas, dapat diketahui bahwa menjadi seorang muslim atau perlu memiliki nilai-nilai agama yang cukup kuat sehingga bisa terejawantahkan dalam kehidupan sehari-hari sebab ajaran, doktrin dan norma agama adalah landasan harus menjadi pegangan.

\section{KEBERAGAMAAN MASYAKAT TANJUNG SEBAUK}

Secara administrasi Tanjung Sebauk terletak di wilayah Kelurahan Senggarang Kecamatan Tanjungpinang Kota Provinsi Kepulauan Riau. Wiayah Tanjung Sebauk secara administrasi berbatasan dengan Pemkab Bintan di sebelah Utara berbatasan dengan Pemerintah Kabupaten Bintan, sebelah selatan berbatasan dengan Senggarang Besar, di sebelah Barat berbatasan dengan Tanjung Geliga, dan di sebalah sebelah Timur berbatasan dengan Senggarang Pusat.

Luas wilayah Tanjung Sebauk yaitu enam kilomter persegi. Luas lahan yang terbagi dalam beberapa peruntukan seperti perda-gangan, perikanan, pertambangan atau galian, fasilitas umum, pemukiman, kegiatan sekolah dan hutan. Kampung Tanjung Sebauk yang berada sangat strategis dan memiliki banyak potensi. Namun keadannya belum nampak pemanfaatan potensi yang ada secara maksimal. Dari profil Tanjung Sebauk terpampang jelas sebanyak 29 dari 101 KK yang tidak mempunyai pekerjaan. Dan tingkat pen didikan dari 293 jiwa di antaranya 12 jiwa berpendidikan tamat S1, 11 jiwa hanya sampai tamat D1- D3, 34 jiwa hanya sampai tamat SMA, 32 jiwa hanya sampai tamat SMP,14 jiwa hanya sampai tamat SD, dan 27 jiwa belum tamat SD.

Tanjung Sebauk diuntungkan dengan lingkungan dan keadaan yang berpotensi. Dan masyarakat Tanjung Sebauk juga memiliki keahlian dalam mengolah makanan dan berderama. Dengan potensi letak tempat keterampilan yang dimiliki dan sumber alam yang ada, Masyarakat Tanjung Sebauk memiliki kesempatan yang besar untuk memperoleh kehidupan yang layak, maju dan berkembang.

Sebagaimana masyarakat di tanah Melayu umumnya, masyarakat Tanjung Sebauk menjalankan tradisi kemelayuan dan keislaman. Hal ini terlihat dari beberapa kegiatan adat istiadat dalam tradisi yang selalu disandarkan pada nilai-nilai agama Islam. Hal ini tidak lepas dari fondasi ajaran Islam yang diyakini oleh masyarakat setempat sebagai keyakinan yang penuh.

Sedangka apabila dilihat dari hasil identifikasi terhadap kondisi obyektif penghidupan di Masyarakat Tanjung Sebauk belum nampak kesan adanya potensi yang melebihi dari yang lain. Dan kenyataan yang ada, kita jumpai keadaannya sama dengan kampung kampung yang lain. Berarti Masyarakat Tanjung Sebauk belum mengambil manfaat dari berbagai nikmat yang telah Allah berikan. Sedangkan agama mengajarkan jangan menyia nyiakan sesuatu dari nikmat Allah. Dengan kondisi ini, tersingkap begitu lemah pengamalan ajaranajaran agama. Supaya potensi yang ada dapat diambil manfaatnya oleh Masyarakat Tanjung Sebauk, harus ada upaya meningkatkan perhatian dan motivasi berupa pendidikan dan pemahaman agama, training dalam kehidupan yang harus didampingi.

Kesempatan untuk meraih apa yang di impikan diberikan sepenuhnya kepada setiap orang. Tidak ada sedikitpun perbedaan dari segala hal. Orang yang 
berhak memperoleh kesempatan dan keberuntungan ini, yang memiliki antara lain:

1. Keyakinan yang mantap tentang konsep Islam. Tidak ada keraguan dari isi bahkan yakin akan kebenarannya. Menyakini dengan kebenaran konsep Islam akan merubah kepada kemajuan sebagaimana yang tertulis dan pengakuan dari pengalaman yang terjadi pada seseorang. Orang kaya, orang miskin, orang kuat, orang lemah, laki laki, wanita, siapapun dia, apapun keadaannya, dan dari manapun asalnya, akan mendapatkan apa yang dimahukan. Keyakinan yang diperoleh orang orang yang sukses tersebut buah dari amal yang dilakukan secara isti- qomah dan keikhlasan.

2. Bersikap aktif, tanpa memandang besar kecil nilai keuntungan dan manfaat. Dengan berkeyakinan tidak ada nilai sia sia dalam suatu kebaikan. Dan meyakini suatu larangan ada mudhoratnya walaupun kecil dan bisa menjadi masalah. Sehingga terus bertambah ilmu dan pemahamaan. Dapat mengetahui permasalahan dengan cepat dan tepat. Dan dapat mengambil kesimpulan serta menentukan apa yang harus dilakukan.

3. Azzam atau kemauan untuk mencapai suatu maksud terkhusus cita-cita dibutuhkan yang namanya kebulatan tekad, tabah dan tekun. Dalam memperjuangkan impian, tidak akan lepas dengan yang namanya ujian, rintangan dan tantangan. Tanpa azam yang kuat mustahil suatu impian akan didapat. Banyak kejadian yang nampaknya mustahil terjadi. Ini bukti Allah akan memberikan sejauh mana usaha seseorang dan sebesar apa pengorbanan yang dilakukan, dihargai dengan pemberian balasan yang lebih baik. Keyakinan yang kuat dan pengetahuan yang luas terbukti semua itu dengan perbuatan. Hadirnya suatu perbuatan setelah ada kebulatan tekad.

Dengan demikian, kondisi masyarakat Tanjung Sebauk secara umum termasuk dalam kalangan menengah ke bawah dengan ketaatan terhadap nilai-nilai agama yang terbilang masih dalam tahapan kalangan abangan. Namun, adanya upanya masyarakat untuk meningkatkan pengetahuan dan pemahaman terhadap ajaran Islam menambah nilai atas upaya untuk menjadikannya sebagai dasar dalam keberagamaa mereka.

\section{KESIMPULAN}

Keberagamaan masyarakat memang identik dengan tingkat pemahaman terhadap ajaran, doktrin dan norma agama yang dipahami dan diyakin oleh masyarakat. Dalam konteks ini, religiusitas masyarakat Tanjung Sebauk sebagaimana umumnya masyarakat di Tanah Melayu dengan tingkat pemahaman dan pengalan nilai-nilai agama yang masih standar. Nilai religiusitas yang terdapat dalam komunitas masyarakat Tanjung Sebauk tercermin dalam praktik adat istiadat kemelayuan yang dilandaskan padan ajaran Islam. Dalam tataran tradisi kemelayuan dan keislaman tersebut, masyarakat Tanjung Sebauk sangat antusias dalam keberagamaan namun secara indivisual dan tingkat pemantapan terhadap ajaran agama masih perlu mendapat perhatian dari berbagai pihak, khususnya dari kalangan ulama atau tokoh agama di Tanjungpinang. []

\section{DAFTAR PUSTAKA}

Abdullah, M. Amin, Studi agama: normativitas atan bistorisitas? (Pustaka Pelajar, 1996) 
Amran, Ali, 'Peranan Agama Dalam Perubahan Sosial Masyarakat', HIKMAH: Jurnal Ilmu Dakwah Dan Komunikasi Islam, 2.1 (2015), 23-39

Friz, Oktaliza, 'Hubungan Antara Harga Diri Terhadap Resiliensi (Ketangguhan Diri) Pada Remaja Di SMA Kartika I-5 Padang' (unpublished $\mathrm{PhD}$ Thesis, UPT. Perpustakaan Unand, 2015)

Hadi, Sutrisno, 'Metode Research', Yogyakarta: Andi Offset, 1987

Harahap, Musaddad, 'Refleksi Dinamika Kebebasan Akademis Dalam Pendidikan Islam', Jurnal Pendidikan Agama Islam Al-Thariqah, 1.1 (2016), 87-103

Indonesia, Majelis Ulama, 'Air, Kebersihan Dan Kesehatan Lingkungan Menurut Ajaran Islam', 2019

Iswahyudin, Iswahyudin, 'Pengaruh Belanja Modal, Belanja Barang Dan Jasa Terhadap Sisa Lebih Pembiayaan Anggaran (Silpa) Kabupaten/Kota Di Sulawesi Tengah', Katalogis, 4.6

Rahmasari, Lisda, 'Pengaruh Kecerdasan Intelektual, Kecerdasan Emosi Dan Kecerdasan Spiritual Terhadap Kinerja Karyawan', Majalah Ilmiah Informatika, 3.1 (2012)

Surakhmad, Winarno, Pengantar Penelitian Ilmiah: Dasar, Metode Dan Teknik (Tarsito, 1990)

Suripto, Teguh, 'Manajemen Sdm Dalam Prespektif Ekonomi Islam: Tinjauan Manajemen Sdm Dalam Industri Bisnis', JESI (Jurnal Ekonomi Syariah Indonesia), 2.2 (2016), 239-50 